\title{
Electrochemical Determination of Sunset Yellow and Tartrazine at Carbon Electrodes Modified by Fe-Zr Oxide
}

\author{
Mohammad F. Khanfar ${ }^{\mathrm{a} *}$, Eyad S. M. Abu-Nameh ${ }^{\mathrm{b}}$, Nawal Al Azizi ${ }^{\mathrm{b}}$, \\ Rund Abu Zurayk ${ }^{c}$, Aya Khalaf ${ }^{d}$, Munib M. Saket ${ }^{a}$ and Nasim Alnuman ${ }^{\mathrm{e}}$ \\ ${ }^{a}$ Pharmaceutical and Chemical Engineering Department, School of Applied Medical Sciences, \\ German Jordanian University, P.O.Box 35247 Amman 11180 Jordan. \\ ${ }^{b}$ Department of Chemistry, Faculty of Science, Al-Balqa Applied University, Al-Salt 19117, \\ Jordan. \\ ${ }^{c}$ Hamdi Mango Center for Scientific Research, The University of Jordan, Amman 11942, \\ Jordan. \\ ${ }^{d}$ Department of Basic Sciences, Faculty of Arts and Science, Al-Ahliyya Amman University, \\ Amman, P. O. Box 19328, Jordan. \\ ${ }^{e}$ Biomedical Engineering Department, School of Applied Medical Sciences, German Jordanian \\ University, P.O.Box 35247 Amman 11180 Jordan.
}

Received: $27^{\text {th }}$ May 2020; $\quad$ Accepted: $31^{\text {th }}$ Jan. 2021

\begin{abstract}
An electrochemical probe, highly sensitive for the detection of two colorants; sunset yellow (SY) and tartrazine (TZ), was examined. The probe was fabricated by modifying carbon electrodes with an iron-zirconium binary transition metal oxide, $\mathrm{Fe}_{2} \mathrm{Zr}_{2} \mathrm{O}_{7}$. In the presence of the oxide, $\mathrm{SY}$ and $\mathrm{TZ}$ exhibit well resolved oxidation peaks at 0.80 and $1.0 \mathrm{~V}$, respectively, in $\mathrm{pH} 2.00$ buffer solution. The developed method exhibits linear response in the range $1.9 \times 10^{-5}-2.7 \times 10^{-4} \mathrm{M}$ for both SY and TZ. The corresponding limits of detection were found to be $5.7 \times 10^{-6} \mathrm{M}$ for SY and $1.3 \times 10^{-5} \mathrm{M}$ for TZ.
\end{abstract}

Keywords: Dyes, Voltammetry, Metal oxides, Oxidation, Soft drinks, Juices.

\section{Introduction}

Sunset yellow (SY) and tartrazine (TZ) are two synthetic azo dyes produced by coupling the sulfanilic acid dizaonium cation with an aromatic nucleophile. Generation of the dyes is an example of electrophilic aromatic substitution, since the azo cation attacks an electron-rich moiety, an aromatic one. Therefore, highly conjugated, and as a consequence, colored products are obtained. When coupling occurs between the diazonium cation and 6-hydroxy-2napthalene-sulfonic acid, sunset yellow is produced, while tartrazine is obtained from the reaction of the cation with 5-oxo-1-(4-sulfophenyl)-2-pyrazoline-3-carboxylic acid. As food additives, SY and TZ are coded as E-110 and E102 , respectively ${ }^{[1,2]}$. Structures of the sodium salts of the dyes are shown in Figure 1.

Over their natural counterparts that originally exist in food, artificial dyes demonstrate stability to light and oxygen exposure, $\mathrm{pH}$ variation over long storage times and microbiological contamination. The addition of colorants, such as E-102 and $\mathrm{E}-110$, is carried out in a controlled manner. The recommended concentration of SY is 50 ppm and it is $100 \mathrm{ppm}$ for TZ, if and only if the colorants are added separately. As a mixture, the total concentration of the two additives must be lower than $100 \mathrm{ppm}^{[3]}$. TZ and SY have been added to a wide range of food categories, such as 
dairy, juices, sweets and bakery. High doses of the colorants may cause serious symptoms, such as anxiety, migraine, depression, blurred vision,

(a)<smiles></smiles>

itching, general weakness, hot sensations and a feeling of suffocation ${ }^{[4]}$.<smiles>[NH3+][OH+]Cc1nn(-c2ccc(S(=O)(=O)[O-])cc2)c(O)c1NNc1ccc(S(=O)(=O)[O-])cc1</smiles>

Figure 1. Chemical structures of (a) sunset yellow and (b) tartrazine.

Sunset yellow and tartrazine are compounds of unique structural features; they are conjugated systems, so they could be easily detected photometrically. Like most of organic compounds, they could be separated and detected by reversed-phase high performance liquid chroma- tography $^{[5-9]}$. In addition, SY and TZ could be oxidized electrochemically, a process that is accompanied by the release of electrons which could be correlated to the quantity of the electrolyzed colorant. The oxidation reactions of SY and TZ are presented in Figure $2^{[10-13]}$.

(a)<smiles>CC(C)CC1C(=O)C=Cc2cc(S(=O)(=O)[O-])ccc2C1N=Nc1ccc(S(=O)(=O)[O-])cc1</smiles>

(b)<smiles>[NH3+][NH2+]C1C(=O)N(c2ccc(S(=O)(=O)[O-])cc2)N=C1C(=O)[OH2+]</smiles>

Figure 2. Oxidation reactions of (a) sunset yellow and (b) tartrazine.

Electrochemical methods are simple, available, selective and convenient to use. By means of electrochemistry, SY and TZ have been detected in this work, as either standards or as ingredients in commercial sweets and juices. The objective of the performed work is estimating the catalytic activity of the binary metallic catalyst $\mathrm{Fe}_{2} \mathrm{Zr}_{2} \mathrm{O}_{7}$ toward the oxidation of SY and TZ. The utilized catalyst has been already found active toward the degradation of methylene blue, under visible light irradiation ${ }^{[14]}$.

\section{Materials and Methods}

Sodium hydroxide, potassium chloride, boric acid and phosphoric acid were all provided by
VWR chemicals, NY, U.S.A. Glacial acetic was purchased from S. D. Fine-Chem., Ltd., Mumbai, India. The dyes were provided by Sigma-Aldrich, MO, U.S.A. All the consumed chemicals are of analytical grade and were used without further purification. The commercial products were purchased from the local market.

The utilized catalyst is the fluorite type $\mathrm{Fe}_{2} \mathrm{Zr}_{2} \mathrm{O}_{7}$ catalyst. Preparation of the catalyst is explained in detail in reference 14 .

The measurements were carried out using Britton-Robinson (B-R) pH 2.00, 4.00 and 10.0 buffer solutions. To prepare the buffer solutions, the appropriate amounts of phosphoric, boric and glacial acetic acids were dissolved in ultrapure Type I water (Ultra Max 372, Yong Lin 
Instrument Co., Ltd, Anyang, Korea). The $\mathrm{pH}$ of the buffer solutions was adjusted by the addition of the required amount of $0.100 \mathrm{M} \mathrm{NaOH}$. The $\mathrm{pH}$ values were determined by SevenGo Duo $\mathrm{pH}$ meter supplied by Mettler-Toledo, AG, Analytical, Schwerzenbach, Switzerland. All the voltammetric experiments were performed in a three-compartment glass cell using $\mathrm{Ag} / \mathrm{AgCl}$ and platinum as reference and counter electrodes, respectively. The glassy carbon working electrode $(3.0 \mathrm{~mm}$ i.d.) was provided by Pine Research Instrumentation, NC, U.S.A. PGSTAT101 Autolab potentiostat (Metrohm, Utrecht, The Netherlands) operated by NOVA 2.2 and connected to a personal computer was used to perform the electrochemical experiments.

For the preparation of the standard solutions, $5.00 \mathrm{mM}$ buffer solutions were used. Standard solutions of SY and TZ were then prepared from the stock by serial dilution. The prepared series was employed for establishing the calibration curve that correlates the dye oxidation peak currents to the corresponding analyte concentrations.

The glassy carbon electrodes (GCEs) were polished, then rinsed with distilled water and airdried. A sample of 3- $\mu$ l drop of previously prepared metal oxide catalyst $(5 \mathrm{mg}$ in $1 \mathrm{ml}$ solution of Nafion (30\%) : ethanol (70\%)) was applied on the dried glassy carbon surface and then left to dry for 15 minutes. The voltammetric measurements were performed using the differential pulse voltammetric (DPV) mode with the following parameters: potential step $0.005 \mathrm{~V}$, modulation amplitude $0.025 \mathrm{~V}$, modulation time $0.05 \mathrm{~s}$, interval time $0.5 \mathrm{~s}$, scan rate $0.0100 \mathrm{~V} / \mathrm{s}$. To establish the calibration curve, the potential of the modified electrode was scanned between 0.00 and $1.30 \mathrm{~V}$ versus $\mathrm{Ag} / \mathrm{AgCl}$. The oxidation peak current obtained from each measurement was plotted versus the corresponding solution concentration.

To obtain the percentage recovery of the colorants in their commercial products using the modified GCEs, $5.00 \mathrm{mg}$ of the solid samples or $12.5 \mathrm{ml}$ of the liquid ones were taken, then transferred to a 100-ml volumetric flask and diluted to the mark with the prepared buffer solutions. The solutions were then sonicated for 10 minutes, filtered and a fraction of the filtrate was pipetted and used for the recovery evaluation. \%Recovery was then estimated based on the following equation:

$$
\% \text { Recovery }=\frac{S_{X+S}-S_{X}}{S_{S}} \times 100 \%
$$

where $S_{X}$ and $S_{S}$ are the oxidation peak current values for the sample and the standard dye solutions, respectively, and $S_{X+S}$ is the oxidation peak current for mixtures of volumes of the standard and the sample solutions. The unknown samples were spiked with the standard ones to obtain the recovery percentages.

\section{Results and Discussion}

In order to assign each of $\mathrm{SY}$ and $\mathrm{TZ}$ oxidation peaks, the voltammetric response of the bare glassy carbon in B-R pH 7.00 aqueous solutions of sunset yellow and tartrazine was explored. As shown in Figure 3, the oxidation of SY occurs at a potential less positive than that reported for TZ. Because of the structural differences between the two dyes, the oxidation of TZ needs a higher over-potential due to the orientation of the electron withdrawing acetate group at the meta position with respect to the oxidation site, the hydroxyl group.

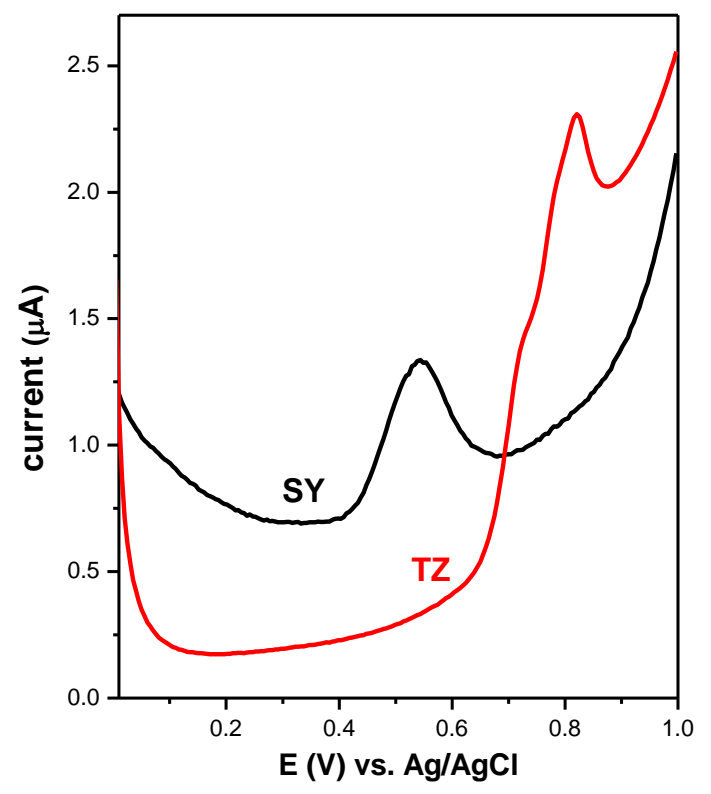

Figure 3. Differential pulse voltammograms of the modified electrode in sunset yellow $\left(5.0 \times 10^{-5} \mathrm{M}\right)$ and tartrazine $\left(5.0 \times 10^{-5} \mathrm{M}\right) \mathrm{pH}$ 7.00 buffer solution. Scan rate $=10 \mathrm{mVs}^{-1}$.

The dependence of the oxidation reactions on $\mathrm{pH}$ encouraged us to investigate the effect of modification in the most acidic media, i.e. in $\mathrm{pH}$ 2.00 buffer solution, as shown in Figure 4. The oxidation of SY and TZ at the modified surface occurs at lower over-potentials compared to the 
unmodified surfaces, with a six-fold enhancement in the oxidation current. The reported activity could be attributed to a couple of factors: the enhancement of the working electrode conductivity (iron zirconium oxide versus carbon), as well as the possible role of the metal cations loaded on the working electrode, $\mathrm{Fe}^{3+}$ and $\mathrm{Zr}^{4+}$, that represent electron deficient centers which are able to oxidize the two dyes ${ }^{[15-17]}$.

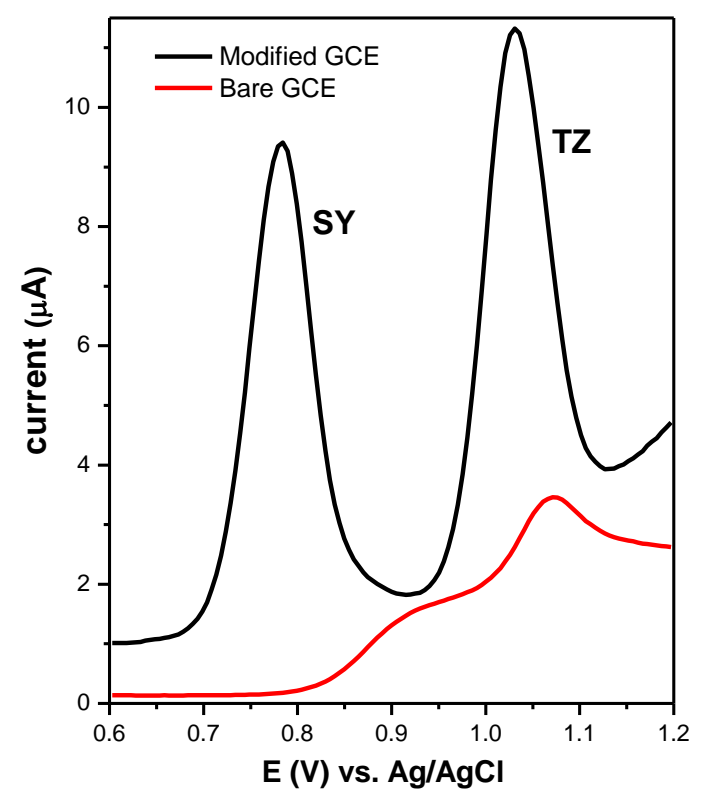

Figure 4. Differential pulse voltammograms of the bare and the modified electrodes in a mixture of sunset yellow $\left(5.0 \times 10^{-5} \mathrm{M}\right)$ and tartrazine $\left(5.0 \times 10^{-5} \mathrm{M}\right)$ at pH 2.00 (B-R buffer solution). Scan rate $=10 \mathrm{mVs}^{-1}$.

The effect of $\mathrm{pH}$ was also investigated in this work, as shown in Figure 5. As the $\mathrm{pH}$ of the working solution increases, features of the oxidation peaks diminish. Therefore, it could be concluded that it is the oxidation of the protonated forms of SY and TZ that takes place. Hence, all the following measurements were performed at $\mathrm{pH} 2.00$, since maximum catalytic activity was reported at that $\mathrm{pH}$ value. Influence of the $\mathrm{pH}$ is a two-fold one; the solution $\mathrm{pH}$ controls the structure of the electro-active species as well as the oxidation of the binary transition metal oxide deposited on the working electrode. From the results reported in Figure 5, the oxidation of the most acidic forms of the dyes is behind the observed peaks. Impact of the employed $\mathrm{pH}$ on the structure of the deposited metals needs further investigation ${ }^{[15]}$.

Figure 6 shows that, for the oxidation performed at the modified surface, a linear dependence of the oxidation current on the scan rate is obtained. This leads to the conclusion that the electrolysis of the two dyes at the modified surface is preceded by adsorption of the electroactive species at the electrode surface. Similar observations were reported by other research groups, at least in the investigated scan rate between 5 and $300 \mathrm{mV} / \mathrm{s}^{[19-21]}$.

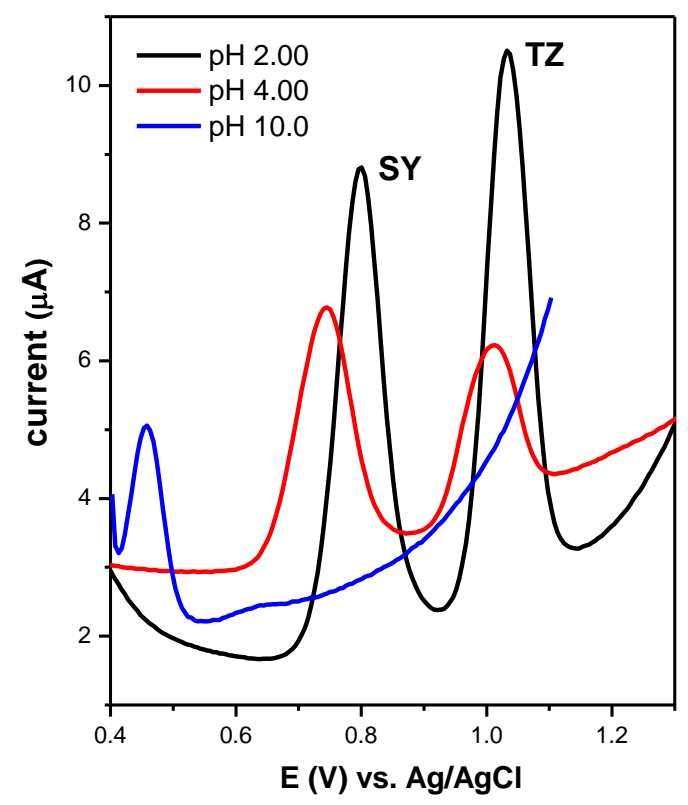

Figure 5. Differential pulse voltammograms of the modified electrode in in a mixture of sunset yellow $\left(5.0 \times 10^{-5} \mathrm{M}\right)$ and tartrazine $\left(5.0 \times 10^{-5} \mathrm{M}\right)$ at $\mathrm{pH} 2.00$, $\mathrm{pH} 4.00$ and $\mathrm{pH} 10.0$ (B-R buffer solutions). Scan rate $=10 \mathrm{mVs}^{-1}$.

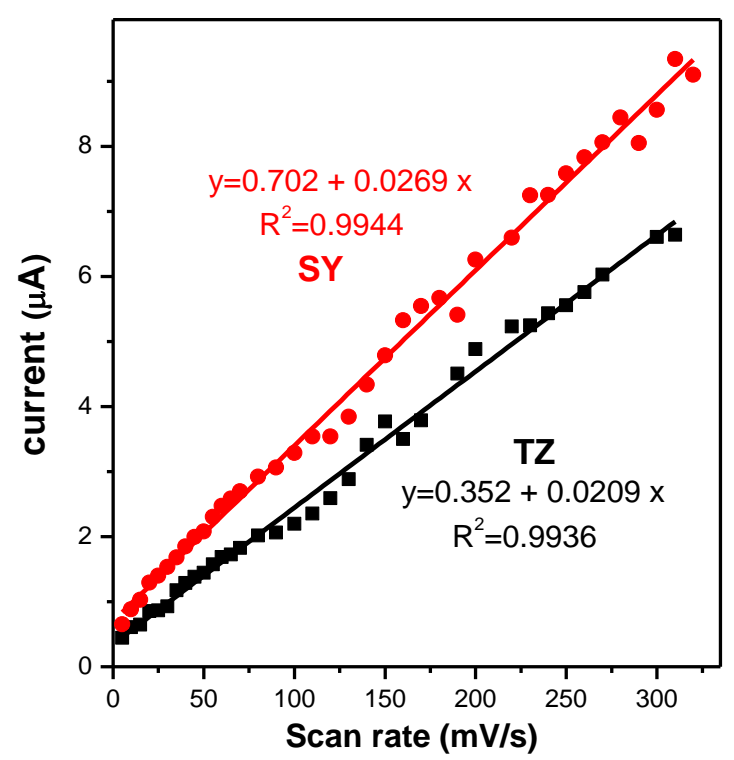

Figure 6. Dependence of oxidation peak current on scan rate when the oxidation was performed at the modified surface in $\mathrm{B}-\mathrm{R} \mathbf{~ p H}$ 2.00 buffer solution: $[\mathrm{SY}]=[\mathrm{TZ}]=5.0 \times 10^{-5} \mathrm{M}$. 
The dependence of the dye oxidation current on the square root of the scan rate was also investigated, where the results (not shown) point to a significant deviation from expected linearity, as concluded from the corresponding correlation coefficient.

In sets of three trials, the dependence of the dye oxidation current values was examined as a function of the dye concentrations, as shown in Figure 7. The dotted line presents the behavior of the employed working electrode in the absence of the dyes. The evaluation was extended to include the dependence of the oxidation charge on the corresponding concentrations, as shown in Figure 8 , where acceptable correlation coefficients were obtained and the limits of detection and quantitation were deduced from the curves. In this context, it is worth to mention that there are cases where the peak current values are not in a linear relationship with concentration. For example, when working electrodes are modified with relatively thick layers of $\mathrm{Fe}-\mathrm{Zr}$ oxide. In such cases, while running differential pulse voltammetric (DPV) experiments, the current values observed at the beginning of the scan are much higher than the corresponding values reported when the corresponding bare unmodified electrodes are used, because of the presence of the added modifiers. As a consequence, the obtained voltammograms may need a background correction, since all of the detected currents will be shifted to higher values if, for example, the oxidation reaction is taking place. Therefore, one could count on peak areas to construct the correlation between charge and concentration and determine the statistical parameters based on the established correlation.

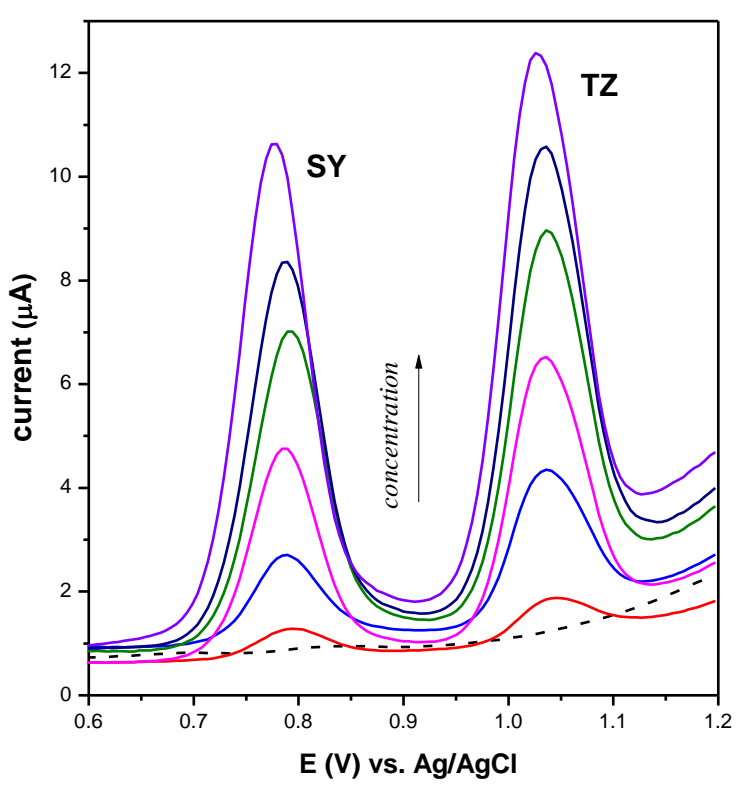

Figure 7. Differential pulse voltammograms of the modified electrode in B-R pH 2.00 buffer solutions containing different concentrations of $S Y\left(1.9 \times 10^{-5}-2.7 \times 10^{-4} \mathrm{M}\right)$ and $\mathrm{TZ}$ $\left(1.9 \times 10^{-5}-2.7 \times 10^{-4} \mathrm{M}\right)$. Scan rate $=10 \mathrm{mVs}^{-1}$.

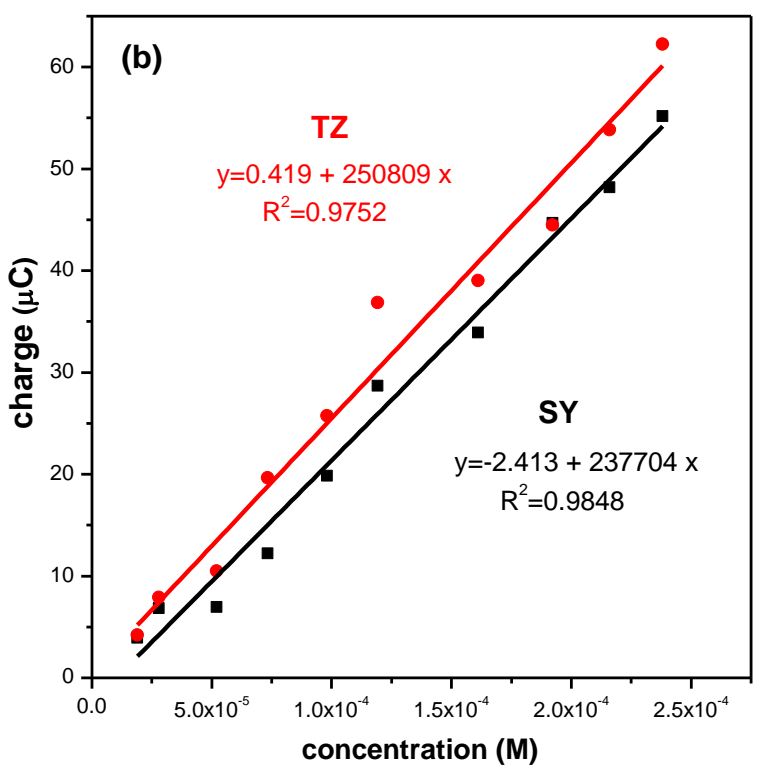

Figure 8. Calibration curves obtained from the voltammetric oxidation of SY and TZ at the modified electrode in B-R pH 2.00 buffer solution, (a) based on the oxidation current and (b) based on the oxidation charge. 
The method was evaluated and found to exhibit linear response in the range $1.9 \times 10^{-5}$ $2.7 \times 10^{-4} \mathrm{M}$ for both dyes. The limit of detection LOD was found to be $5.7 \times 10^{-6} \mathrm{M}$ and $1.3 \times 10^{-5}$ $\mathrm{M}$ for SY and TZ, respectively, and the limit of quantitation LOQ was $1.9 \times 10^{-5} \mathrm{M}$ and $4.2 \times 10^{-5}$ $\mathrm{M}$ for SY and TZ, respectively. The LOD and the LOQ numerical values were calculated using the following equations:

$$
\mathrm{LOD}=\frac{3 \sigma}{s} \quad \mathrm{LOQ}=\frac{10 \sigma}{s}
$$

where $\sigma$ is the standard deviation of the blank and $s$ is the slope of the calibration curve.

The percentages of recovery of the two dyes in commercial products are listed in Table 1 . The recovery percentages are within the acceptable range between 80 and $120 \%$, which reflects the performance of the developed method. Figure 9 shows how $\%$ recovery of TZ in a soft drink was estimated. The reported amounts of SY and TZ in the investigated products are all within the allowed range. It is recommended that the concentration of any, if existing as individual components or as a combination, should not exceed $100 \mathrm{ppm}$. For example, in the commercial juice powder, the total amount of the two dyes is almost $15.9 \mathrm{ppm}$ and it is $69.5 \mathrm{ppm}$ for $\mathrm{TZ}$ in the green drink.

Table 1. Detection of SY and TZ in commercial products using the modified electrode.

\begin{tabular}{ccccc}
\hline Commercial Product & $\begin{array}{c}\text { \% Recovery } \\
(\text { SY) }\end{array}$ & $\begin{array}{c}\text { \% Recovery } \\
(\mathbf{T Z})\end{array}$ & $\begin{array}{c}\text { SY Content } \\
(\mathbf{p p m})\end{array}$ & $\begin{array}{c}\text { TZ Content } \\
(\mathbf{p p m})\end{array}$ \\
\hline Powder Orange Juice & 115 & 81.0 & 4.46 & 11.4 \\
Green Soft Drink & N.A. & 89.3 & N.A. & 69.5 \\
\hline
\end{tabular}

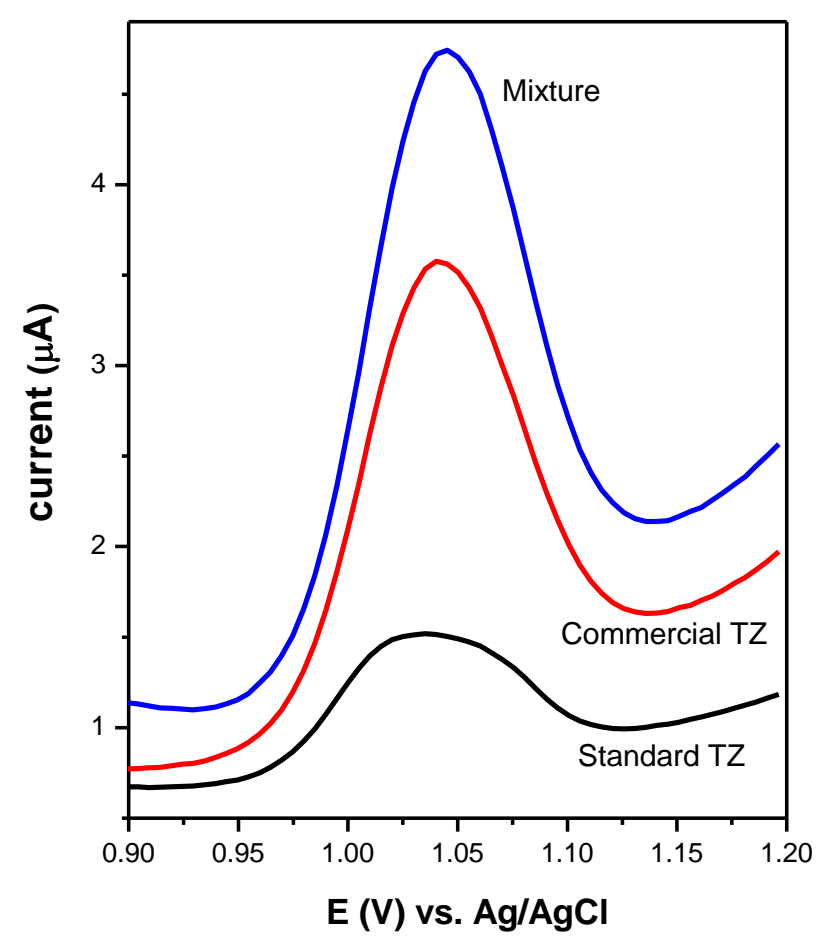

Figure 9. Differential pulse voltammograms of the modified electrode in standard TZ, commercial juice containing TZ and their combination in B-R pH 2.00 buffer solutions. Scan rate $=10 \mathrm{mVs}^{-1}$.

A comparison of the developed method with other methods that have been used for SY and $\mathrm{TZ}$ analysis is presented in Table 2. As shown in Table 2, the electrode utilized in this work, when compared to the others, needs further improve- ment. That may include the employment of transition metals other than the ones used, increasing the catalyst surface or both. All the parameters and figures of merit reported in this work are summarized in Table 3. 
Table 2. Detection of SY and TZ by different modified electrodes.

\begin{tabular}{|c|c|c|c|c|}
\hline Catalyst & Samples & $\begin{array}{l}\text { Working Range } \\
\text { SY/TZ }\end{array}$ & $\begin{array}{l}\text { LOD } \\
\text { SY/TZ }\end{array}$ & Reference \\
\hline $\begin{array}{l}\text { Multi-walled Carbon } \\
\text { Nanotubes }\end{array}$ & Soft Drinks & $\begin{array}{l}55.3 \mathrm{nM} \text { to } 11.1 \mu \mathrm{M} \\
37.4-74.9 \mu \mathrm{M}\end{array}$ & $\begin{array}{l}2.2 \times 10^{-8} \mathrm{M} \\
1.88 \times 10^{-7} \mathrm{M}\end{array}$ & 22 \\
\hline $\begin{array}{c}\text { Gold Nanoparticles Carbon } \\
\text { Paste }\end{array}$ & Soft Drinks & $0.050-1.6 \mu \mathrm{M}$ & $\begin{array}{l}3.0 \times 10^{-8} \mathrm{M} \\
2.0 \times 10^{-9} \mathrm{M}\end{array}$ & 23 \\
\hline $\begin{array}{l}\text { Graphene Decorated with } \\
\text { Nickel Nanoparticles }\end{array}$ & $\begin{array}{l}\text { Extracts from } \\
\text { Food }\end{array}$ & $\begin{array}{l}7.37-442 \mathrm{nM} \\
6.24-624 \mathrm{nM}\end{array}$ & $\begin{array}{l}2.16 \mathrm{nM} \\
1.08 \mathrm{nM}\end{array}$ & 24 \\
\hline $\begin{array}{l}\text { Poly(L-Phenylalanine)- } \\
\text { Modified Glassy Carbon }\end{array}$ & $\begin{array}{l}\text { Food and Drug } \\
\text { Samples }\end{array}$ & $\begin{array}{l}40.0-140 \mu \mathrm{M} \\
40.0-165 \mu \mathrm{M}\end{array}$ & $\begin{array}{c}4.00 \mu \mathrm{M} \\
0.0200 \mu \mathrm{M}\end{array}$ & 25 \\
\hline Magnetic Core-Shell $\mathrm{Fe}_{3} \mathrm{O}_{4}$ & Food Products & $0.5-100 \mu \mathrm{M}$ & $\begin{array}{l}0.05 \mu \mathrm{M} \\
0.04 \mu \mathrm{M}\end{array}$ & 26 \\
\hline $\begin{array}{l}\text { Nanohybrid of Gold } \\
\text { Nanorods Decorated } \\
\text { Graphene Oxide }\end{array}$ & $\begin{array}{l}\text { Soft Drinks and } \\
\text { Food }\end{array}$ & $\begin{array}{l}0.01-3.0 \mu \mathrm{M} \\
0.03-6.0 \mu \mathrm{M}\end{array}$ & $\begin{array}{l}2.4 \mathrm{nM} \\
8.6 \mathrm{nM}\end{array}$ & 27 \\
\hline $\begin{array}{l}\mathrm{ZnO} / \text { cysteic Acid } \\
\text { Nanocomposite }\end{array}$ & Soft Drinks & $\begin{array}{c}0.1-3.0 \mu \mathrm{M} \\
0.07-1.86 \mu \mathrm{M}\end{array}$ & $\begin{array}{l}0.03 \mu \mathrm{M} \\
0.01 \mu \mathrm{M}\end{array}$ & 28 \\
\hline $\begin{array}{l}\text { Metal Oxides Modified } \\
\text { Glassy Carbon }\end{array}$ & Soft Drinks & $19-270 \mu \mathrm{M}$ & $\begin{array}{l}5.7 \mu \mathrm{M} \\
13 \mu \mathrm{M}\end{array}$ & This Work \\
\hline
\end{tabular}

Table 3. Summary of the reported parameters and figures of merit.

\begin{tabular}{cc}
\hline Optimal pH & $\mathbf{2 . 0 0}$ \\
\hline SY oxidation potential $(\mathrm{V})$ & 0.800 \\
TZ oxidation potential $(\mathrm{V})$ & 1.00 \\
Linear range & $19-270 \mu \mathrm{M}$ \\
LOD (SY) & $5.7 \mu \mathrm{M}$ \\
LOQ (SY) & $13 \mu \mathrm{M}$ \\
LOD (TZ) & $19 \mu \mathrm{M}$ \\
LOQ (TZ) & $42 \mu \mathrm{M}$ \\
\hline
\end{tabular}

\section{Conclusions}

In this work, the detection of sunset yellow and tartrazine, as standards or as ingredients in commercial products, was achieved successfully. The detection was carried out at an Fe- $\mathrm{Zr}$ oxide modified surface. The reported catalytic activity could be attributed to the acceleration of the electron transfer rate across the electrodeelectrolyte interface, which could be attributed to the nature of the catalyst or due to formation of electron-deficient centers, which facilitates the oxidation of both of SY and TZ at the modified surface.

\section{Acknowledgments}

The authors would like to thank the Schools of Graduate Studies at the German Jordanian University and at Al Balqa Applied University for their support. 


\section{References}

[1] Tami, K.; Popova, A.; Proni, G., J. Chem. $E d u$., 2017, 94, 471-475.

[2] Kobylewski, S.; Jacobson, M. F., Food Dyes: A Rainbow of Risks, $1^{\text {st }}$ Edition, Center for Science in the Public Interest, Washington, 2010.

[3] Šuleková, M.; Hudák, A.; Smrčová, M., Molecules, 2016, 21, 1368 (8 pages).

[4] Perdomo, Y.; Arancibia, V.; García-Beltrán, O.; Nagles, E., Sensors, 2017, 17, 2665 (10 pages).

[5] Yoshioka, N.; Ichihashi, K., Talanta, 2008, 74, 1408-1413.

[6] Sha, O.; Zhu, X.; Feng, Y.; Ma, W., J. Anal. Methods Chem., 2014, 964273 (8 pages).

[7] Minioti, K. S.; Sakellariou, C. F.; Thomaidis N.S., Anal. Chimca Acta, 2007, 583, 103 110.

[8] López-de-Alba, P. L.; López-Martínez, L.; De-León-Rodríguez, L. M., Electroanalysis, 2002, 14, 197-205.

[9] El-Sheikh, A. H.; Al-Degs, Y. S., Dyes Pigments, 2013, 97, 330-339.

[10] Deng, K.; Li, C.; Li, X.; Huang, H., J. Electroanal. Chem., 2016, 780, 296-302.

[11] Gómez, M.; Arancibia, V.; Aliaga, M.; Núñez, C.; Rojas-Romo, C., Food Chem., 2016, 212, 807-813.

[12] Jampasa, S.; Siangproh, W.; Duangmal, K.; Chailapakul, O., Talanta, 2016, 160, 113124.

[13] Song, Y. Z., Can. J. Chem., 2010, 88, 676681.

[14] Abbas, H. A.; Nasr, R. A.; Khalaf, A.; Al Bawab, A.; Jamil, T. S., Ecotoxicol. Environ. Saf., 2020, 196, 110518 (10 pages).
[15] Ureta-Zan Artu, M. S.; Mora, M. L.; Diez, M. C.; Berrios, C.; Ojeda, J.; Gutierrz, R., J. Appl. Electrochem., 2002, 32, 1211-1218.

[16] Dicu, D.; Munteanu, F.-D.; Popescu, I. C.; Gorton, L., Analytical Letters, 2003, 36, 1755-1779.

[17] Abazović, N. D.; Savić, T. D.; Novaković, T. B.; Čomor, M. I.; Mojović, Z. D., J. Serb. Chem. Soc., 2020, 85 (11 pages).

[18] Gómez, M.; Arancibia, V.; Rojas, C.; Nagles, E., Int. J. Electrochem. Sci., 2012, 7 , 7493-7502.

[19] Ya, Y.; Jiang, C.; Li, T.; Liao, J.; Fan, Y.; Wei, Y.; Yan, F.; Xie, L., Sensors, 2017, 17, 545 (9 pages).

[20] Sun, D.; Xu, C.; Long, J.; Ge, T., Microchim. Acta, 2015, 182, 2601-2606.

[21] Wang, J.; Yang, B.; Wang, H.; Yang, P.; Du, Y., Analytica Chimica Acta, 2015, 893, 41-48.

[22] Zhanga W.; Liua, T.; Zhengb, X.; Huangb, W.; Wana C., Colloids Surf. B: Biointerfaces, 2009, 74, 28-31.

[23] Ghoreishi, S. M.; Behpour, M.; Golestaneh, M., Food Chem., 2012, 132, 637-641.

[24] Gan, T.; Sun, J.; Wu, Q.; Jing, Q.; Yu, S., Electroanalysis, 2013, 25, 1505-1512.

[25] Chao, M.; Ma, X., Food Anal. Methods, 2015, 8, 130-138.

[26] Arvand, M.; Parhizi, Y.; Mirfathi, S. H., Food Anal. Methods, 2016, 9, 863-875.

[27] Deng, K.; Li, C.; Li X.; Huang, H., J. Electroanal. Chem., 2016, 780, 296-302.

[28] Dorraji, P. S.; Jalali, F., Food Chem., 2017, 227, 73-77. 